\title{
Growing in the city: Expanding opportumities for uban food production in Victoria, Canada
}

Virginie Lavallée-Picard * CONNECTIONS

City of Victoria, Canada

Submitted January 3, 2018 / Revised April 6 and June 22, 2018 / Accepted July 16, 2018 /

Published online O ctober 17, 2018

Citation: Lavallée-Picard, V. (2018). Growing in the city: Expanding opportunities for urban

food production in Victoria, Canada. Journal of A griculture, Food Systems, and C ommunity

D evelopment, 8(Suppl. 2), 157-173. https:/ / doi.org/ 10.5304/ jafscd.2018.08B.005

Copyright (C) 2018 by the Author. Published by the Lyson Center for Civic Agriculture and Food Systems. Open access under CC BY license.

\begin{abstract}
Growing in the City is a municipally led initiative developed to increase the amount of food grown within the City of Victoria. A comprehensive strategy to update and expand policies and programs enabling urban food production was launched in 2016. This paper describes the project background, the nature and goals of the policy and program changes, and the implementation process and early outcomes. It focuses on the specific initiatives that enable small-scale commercial urban food production, and on community programs that support urban food production in the public realm. These programs include community gardens, boulevard gardening, an inventory of city-owned land with community gardening potential, and a pilot program to plant food trees on city land. This paper explores if and how Growing in the City is achieving its goals to identify and discuss success factors,

* Virginie Lavallée-Picard, Food Systems Coordinator, City of Victoria; 1 Centennial Square, Victoria, BC, V8W 1P6 Canada; vlavallee-picard@victoria.ca
\end{abstract}

challenges and areas for improvement. The conclusion provides general observations and considerations for the ongoing integration of food systems into city planning.

\section{Keywords}

Urban Agriculture, Community G ardens, Food Production, Food Systems Planning, Boulevard Garden, Food Policy, Land Inventory

\section{Introduction}

In Canada, the jurisdictional authority of local governments over their food system is limited, yet local governments are also service providers with the power to educate, enact policies, and support community-driven initiatives that shape food systems. Pothukuchi and Kaufman $(1999,2000)$ were among the first to argue that since the food system affects urban quality of life, it is critical for

\section{Disclosure}

The author is an employee of the City of Victoria, and works as the food systems coordinator for the city. 
local governmental institutions to contribute to developing a more comprehensive understanding of food systems (Pothukuchi \& Kaufman, 1999) and to explore how planners could strengthen food systems by engaging in food system planning (Pothukuchi \& Kaufman, 2000). In 2018, the body of research pertaining to food system planning continues to grow and the planning community is increasingly playing a role in efforts to create more just and sustainable food systems (Morgan, 2009, 2013; Soma \& Wakefield, 2011).

Recent research also shows how municipalities have or could devise integrated food policies and strategies inclusive of a full spectrum of food systems issues, ranging from urban food production, processing, distribution, and access, to waste management (Mansfield \& Mendes, 2013; Morgan \& Sonnino, 2010; Sonnino, 2009). The role of municipalities in increasing opportunities for urban food production has emerged as an area of focus for both academics and practitioners. Recent examples of resources focused on urban food production include the American Planning Association publication "Urban Agriculture: G rowing Healthy, Sustainable Places" (Hodgson, AICP, Campbell, \& Bailkey, 2011), the report "Continuous Productive Urban Landscapes: D esigning Urban Agriculture for Sustainable Cities" published by Architectural Press (Viljoen, Bohn, \& Howe, 2005), as well as "Agricultural Urbanism: Handbook for Building Sustainable Food \& Agriculture Systems in the 21st Century Cities" (de la Salle \& Holland, 2010). Other examples of academic research include investigations on the resurgence of livestock in urban contexts (Butler, 2012); how land inventories can enable the integration of urban agriculture into planning and policy-making (Mendes, Balmer, Kaethler, \& Rhoads, 2008); the impact of zoning in expanding urban agriculture (McClintock, Wooten, \& Brown, 2012); and the role of community gardens in enhancing health and well-being (Armstrong, 2000; D raper \& Freedman, 2010; Ferris, Norman, \& Sempik, 2001; Twiss, Dickinson, D uma, Kleinman, Paulsen, \& Rilveria, 2003). Noteworthy research led by Rod MacRae (2010, 2012) focused on the production potential of urban agriculture to meet a portion of commercial demand while exploring what policy supports and programs would be required (MacRae, Gallant, Patel, Michalak, Bunch, \& Schaffner, 2010; MacRae et al., 2012).

This paper builds on the growing body of literature focused on how municipal urban governments are taking a comprehensive approach to enabling urban food production. The paper outlines the process and outcomes of $\mathrm{G}$ rowing in the City (GITC), a municipally led initiative to update and expand policies and guidelines for urban food production in the City of Victoria. This paper provides an overview of G ITC from a project development and implementation perspective, discussing the project background, the nature and goals of the policy and program changes, the implementation process, and early project outcomes. This paper focuses on the specific initiatives designed to enable small-scale commercial urban food production. It also focuses on the programs aiming to support community food production in the public realm, including community gardens, boulevard gardening, an inventory of city-owned land with community gardening potential, and a pilot program to plant food trees in city-owned green spaces. While this paper does not examine the citizen experience with the GITC process and outcomes, it explores if and how the project is achieving its goals to identify and discuss success factors, challenges, and areas for improvement. The conclusion provides general observations on the ongoing integration of food systems considerations to city planning, policies, and regulations.

\section{Research Methodology}

This paper uses a qualitative research approach to present a case study of the City of Victoria. The author is an employee of the City of Victoria, and works as food systems coordinator, a position that was created to implement G ITC. This paper draws on the review of G ITC reports prepared by city employees starting in 2015 and presented to City Council in February 2016. These reports present background information and community engagement results to analyze the issue at hand and provide recommendations for Council to consider. The methods used to develop the GITC recommendations included surveys, roundtable discussions, and interviews. They are further detailed in 
the section "Collaboration and Community

Engagement." The paper draws on participatory observation by city employees (including the author of this paper) currently involved in implementing the GITC policy and program changes and monitoring outcomes. The paper also presents secondary data from Statistics Canada.

\section{Background}

The City of Victoria is the provincial capital of British Columbia, Canada. Located on the southern tip of Vancouver Island, on the traditional territory of the Lekwungen People, Victoria is a harbour city with an extensive shoreline. With a total area of 19.47 square kilometers ( 7.52 square miles) (Statistics Canada, 2017a) and 4,405.8 residents per square kilometer, in 2016 Victoria was the seventh most densely populated city in Canada (Statistics Canada, 2017b). Divided into 13 neighborhoods, Victoria has a total population of 85,792 within a regional district of 383,360 residents (Statistics Canada, 2017a). Victoria is the core urban municipality in the Capital Regional District (CRD), a regional government administrative district encompassing the southern end of Vancouver Island and the southern Gulf Islands. Figure 1 shows the location of Victoria within the CRD.

Victoria is a built-out city with little remaining undeveloped land and is committed to accommodating a share of the region's projected population growth (City of Victoria, 2016m). Between 2011 and 2016, the Victoria population increased by $7.2 \%$ (Statistics Canada, 2017a). In 2016, 61\% of Victoria households rented compared to $37 \%$ in the CRD (Statistics Canada, 2016b) and Victoria vacancy rates were 0.6\% in O ctober 2015 (Canada
Mortgage and Housing Corporation, 2015). Victoria is forecasted to need an additional 13,500 apartment units and an additional 2,700 ground-oriented dwellings ${ }^{1}$ by 2041 (City of Victoria, 2012).

Regional food and farmlands are important aspects of Victoria's and the CRD's history, identity, and ongoing sustainability. However, the region's traditional agriculture sector is declining, as indicated by a decrease in total farmland area of 842 acres from 2011 to 2016 (Statistics Canada, 2016c), an increase in the average age of farmers from in 57.4 in 2011 to 57.5 in 2016, compared to a national average of 55 in 2016 (Statistics Canada, 2016a), and a decrease in the number of farm operators from 1,660 in 2011 to 1,495 in 2016 (Statistics Canada, 2016c). Because Vancouver Island imports the vast majority of its food, the regional trends create concerns for the future cost and stability of the food supply. In light of these challenges, the CRD adopted a Regional Food and Agriculture Strategy in 2016 to support the development and future success of food and agriculture across the region (Capital Regional District, 2016). The Regional Food and Agriculture Task Force
Figure 1. Map of Vancouver Island Showing the Location of Victoria and the Capital Regional District (CRD)

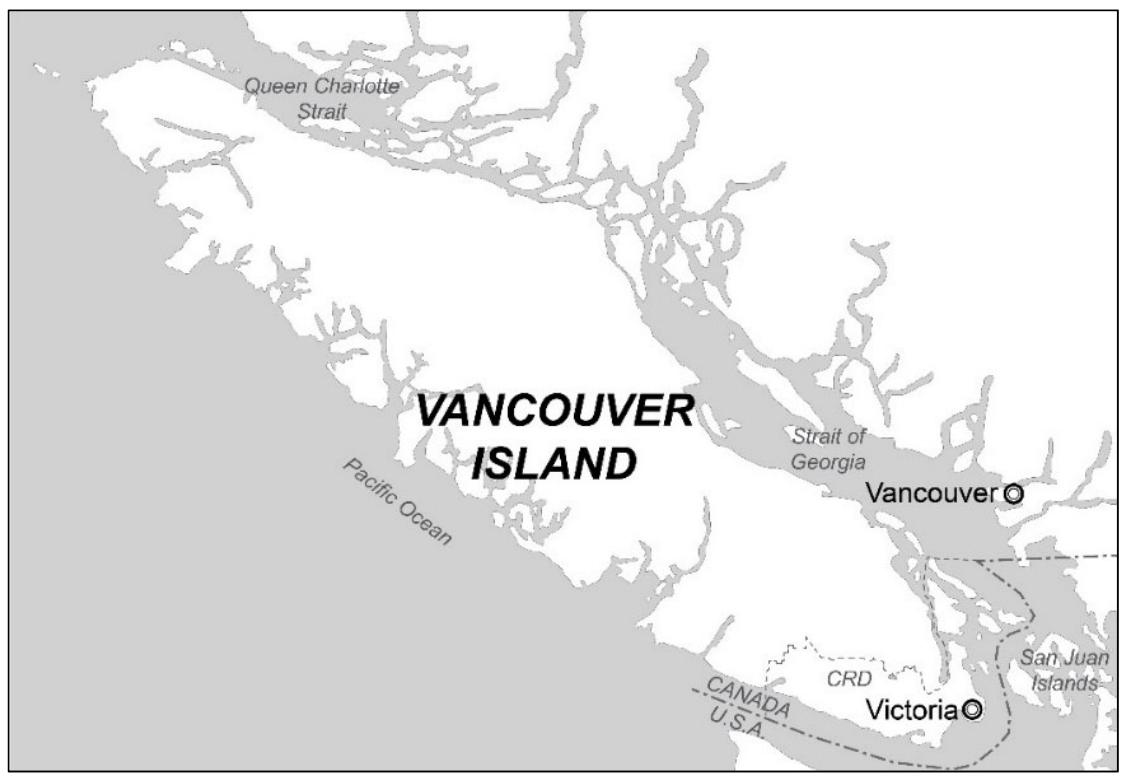

\footnotetext{
${ }^{1}$ A ground-oriented dwelling is a residential unit that has individual and direct access to the ground, whether detached or attached; the category includes single-detached dwellings, duplexes, rowhouses, and townhouses, as well as the principal unit and secondary suite in a single-detached dwelling.
} 
was created to support the CRD in implementing the recommendations of the Regional Food and Agriculture Strategy.

Victoria is located in a sub-Mediterranean zone, providing some of the most moderate weather in all of Canada and a good environment for year-round gardening and food production. Victoria's public parks and open spaces encompass 207 hectares (511 acres) of municipal parks and open spaces and approximately 132 hectares (326 acres) of other public open spaces (City of Victoria, 2017a).

In 2017, there were 18 community gardens in the city, 14 of which were situated on city-owned land, and four of which were situated on school district or private land. The O fficial Community Plan (O CP) targets a minimum of one allotment garden per neighborhood (City of Victoria, 2012). Currently, eight of 13 neighborhoods do not have an allotment garden, and all allotment gardens are reported to have a full waiting list. City grants that support community gardening include placemaking grants to animate underutilized community spaces (up to CA $\$ 5,000$ per project), microgrants to purchase gardening supplies in community gardens (up to CA \$500), and community garden volunteer coordinator grants available to neighborhoods with community gardens to provide funding for a person to coordinate volunteers (up to CA \$6,000 per neighborhood). O ther granting streams that can support community gardening include the strategic plan grants that support projects aligned with the city's 2015-2018 Strategic Plan objectives, and the participatory budgeting process grants. Launched in 2017, the participatory budgeting process empowers the community to decide what to do with a portion of the city budget. A total of CA \$52,500 was awarded in the first year of the program. Two of the three projects that received the most votes and won the participatory budgeting grants focused on urban gardening: A pop-up native bee apiary installed at a downtown community garden, and a learning garden and educational outdoor classroom at the Greater Victoria Public Library's downtown branch.

Many Victorians grow a portion of their food in private backyards, balconies, and rooftops, as well as in community gardens or other green spaces. Numerous households keep backyard chickens and bee hives. The Animal Control Bylaw (City of Victoria, 2015a) allows poultry and bee hives, with few restrictions, making it one of the most permissive in North America. Several nonprofit organizations provide educational resources supporting gardening and food production in the city, many of which are long-standing groups considered pioneers of urban agriculture in Canada. Victoria enjoys a vibrant local food scene brought to life by an abundance of restaurants, local producers, community gardens, two farmers markets, nongovernmental organizations, and residents who champion local food.

G rowing in the City (G ITC): Key Policy D irectives In the City of Victoria, key food systems directives come from the OCP adopted in 2012 (City of Victoria, 2012). In 2012, Victoria became one of the few municipalities in Canada to have a standalone OCP chapter on food systems. Chapter 17 of the OCP, titled "Food Systems," directs the city to increase opportunities for urban food production in the private and public realms. These policies aim to move Victoria's food system toward increased local food production and greater access to the skills, knowledge, and resources to produce and process food in urban areas.

The 2015-2018 Strategic Plan (City of Victoria, 2015c) is a road map developed by Council to guide decision making during their terms of office. "O bjective 8: Enhance Public Spaces, Green Spaces, and Food Systems" (City of Victoria, 2015) identifies priority food systems action, including the development of food systems policies, programs and grants to support gardening and food production in public spaces.

To advance these key O CP directions, G ITC was launched in 2015 with the goal of delivering six specific initiatives:

1. A review and update of the municipal Community Gardens Policy;

2. An inventory of city-owned land for community food production;

3. G uidelines for food-bearing trees on cityheld lands; 
4. A final version of the Boulevard Gardening Guidelines;

5. A review of city regulations and policies to explore the opportunity for, and implications of, supporting expanded small-scale commercial urban agriculture; and

6. Voluntary guidelines for food production in multi-unit, mixed use developments and other types of housing. ${ }^{2}$

Policy Process: Collaboration and Community E ngagement

GITC presented a unique opportunity to work in partnership across and within city departments, with the regional health authority, and with local organizations and community members. The development and delivery of G ITC was led by the D epartment of Parks, Recreation and Facilities (herein "Parks"); the D epartment of Sustainable Planning and Community D evelopment (herein "Planning"); and the D epartment of Engagement (herein "Engagement"). In collaboration with the departments of Engineering and Public Works, Finance, Legal, and Legislative and Regulatory Services, Parks and Planning staff consulted community stakeholders, conducted background research, and developed proposed programs and regulations. City staff also worked with Island Heath, the regional health authority overseeing food safety, to ensure proposed changes in city regulations were aligned with provincial and regional regulations and guidelines.

Parks, Planning, and Engagement developed an engagement process to solicit input from diverse stakeholders ranging from the general public to local food experts. From June to $\mathrm{O}$ ctober 2015, city staff conducted a first round of public engagement, which consisted of seven one-on-one interviews with urban farmers, an online survey $(\mathrm{n}=809)$, pop-up engagement stations at local farmers markets, and a series of meetings among city staff and urban food system professionals, distributors and purchasers. City staff also hosted a roundtable event with representatives of the Urban Food Table, the city's advisory group for urban food production. Stakeholders were asked to reflect on opportunities and barriers to increase urban food production. Feedback received in this first stage of engagement guided staff in their preparation of potential changes to policies, guidelines and regulations. A second round of public engagement was held from November 2015 to January 2016, which solicited feedback on the draft changes through another roundtable meeting with the Urban Food Table, an open house, a policy review workshop, and a second online survey $(\mathrm{n}=236)$.

\section{GITC Policy and Program Changes}

In February 2016, the proposed changes were presented to Council in two reports developed collaboratively by the departments of Parks and Planning. Presented by Parks, the report ' $G$ rowing in the City' - Part 1: U rban F ood Production on City-0 wned L ands (City of Victoria, 2016f) updated policies and guidelines and introduced new programs to support community food production in the public realm. Presented by Planning, the report ' $G$ rowing in the City'- Part 2: Regulatory A mendments to Support Small-Scale C ommercial U rban Farming (City of Victoria, 2016g) proposed bylaw amendments to enable the sale of food products grown in the city. Key policy and program changes enacted by G ITC are summarized in Table 1 and described in the section below.

\section{U rban F ood Production in the Public Realm}

(G IT C Part 1)

City staff with Parks reviewed and developed policy and programs to increase the number of allotment gardens, commons gardens, edible landscapes, and food-bearing trees in the public realm based on community preferences. The community preference expressed in the first online survey indicated a high level of support for increasing opportunities for food production in public spaces: Of the 809 respondents, $98 \%$ supported an increase in the number of community orchards; $94 \%$ supported an increase in the number of boulevard gardens; and, 91\% supported an increase in the number of community gardens (City of Victoria, 2015d). Most survey respondents connected

2 The development of these voluntary guidelines was ongoing at the time this paper was submitted. 
Table 1. Key GITC Policy and Program Changes

\begin{tabular}{ll}
\hline Urban Food Production in the Public Realm (GITC Part 1) & Impact \\
\hline Program or policy & $\begin{array}{l}\text { Improves opportunities for residents to initiate and } \\
\text { participate in community gardens }\end{array}$ \\
\hline Revised Community Gardens Policy & $\begin{array}{l}\text { Helps residents identify city-owned lands for new community } \\
\text { gardening projects }\end{array}$ \\
\hline $\begin{array}{l}\text { Inventory of city-owned land with community gardening } \\
\text { potential }\end{array}$ & $\begin{array}{l}\text { Residents can apply to plant and maintain up to five food } \\
\text { trees in parks and greenspaces }\end{array}$ \\
\hline Urban Food Tree Stewardship Pilot Program & Allows boulevard gardens throughout the city \\
\hline $\begin{array}{l}\text { Boulevard Gardening Guidelines and amendment of the } \\
\text { Streets and Traffic Bylaw No. 09-079 }\end{array}$ & $\begin{array}{l}\text { Impact } \\
\text { Regulatory Amendments to Support Small-scale Commercial Urban Food Production (GITC Part 2) }\end{array}$ \\
\hline Selected bylaw amendments & $\begin{array}{l}\text { Defines allowed products; allows commercial food stand } \\
\text { sales on lot where product is grown }\end{array}$ \\
\hline $\begin{array}{l}\text { Zoning Regulation Bylaw No. 80-159 } \\
\text { Schedule L: Small-Scale Commercial Urban Food Production }\end{array}$ & $\begin{array}{l}\text { Allows commercial urban agriculture in all zones; exempts } \\
\text { small rooftop greenhouses from height and density } \\
\text { calculations }\end{array}$ \\
\hline $\begin{array}{l}\text { Zoning Regulation Bylaw No. 80-159 } \\
\text { Introduction and General Regulations }\end{array}$ & $\begin{array}{l}\text { Defines "Small-scale commercial urban food production," } \\
\text { "Greenhouse" and "Foodstand" }\end{array}$ \\
\hline $\begin{array}{l}\text { Zoning Regulation Bylaw No. 80-159 } \\
\text { Schedule A: Definitions }\end{array}$ & $\begin{array}{l}\text { Permits on-site and off-site sales of food products provided } \\
\text { a business licence is obtained }\end{array}$ \\
\hline Business Licence Bylaw No. 89-071 & $\begin{array}{l}\text { Restricts the use of pesticides in small-scale commercial } \\
\text { urban food production }\end{array}$ \\
\hline Pesticide Use Reduction Bylaw No. 07-094 & \\
\hline
\end{tabular}

increased food production in the public realm with food security, educational opportunities, and community-building, as illustrated below.

In order to address food security concerns, we should be growing as much food as possible in as many places as possible, and be as inclusive as possible in our definitions. (City of Victoria, 2015h)

More fruit and nut trees in the City is a good thing. People taking responsibility and working together and free food! (City of Victoria, 2016h)

We must begin to educate ourselves and our friends, neighbours and families about the source of our food and the importance of learning to grow, harvest and preserve it, Also, it is imperative that all regardless of their status and ownership of anything participate in these initiatives. (City of Victoria, 2015d)
Some respondents expressed concerned about the potential impact of increased food production on public space and resources:

It should be up to individual property owners whether they want to grow food or not, it isn't something the tax payer should have to finance, and it isn't something to sacrifice our scarce parks land for. (City of Victoria, 2015d)

Revisions to the $\mathrm{C}$ ommunity $\mathrm{G}$ ardens Policy The Community G ardens Policy, originally approved in 2003, outlines the process for the creation and sustenance of community garden sites on city-owned lands (see Figure 2), which are operated by nonprofit societies (usually neighborhood associations). The nonprofit society enters into a three-year licence agreement with the city and is required to carry liability insurance. The city does not build or maintain community gardens. All community gardening projects are volunteer-led. 
Figure 2. Existing Community Gardens on VicMap

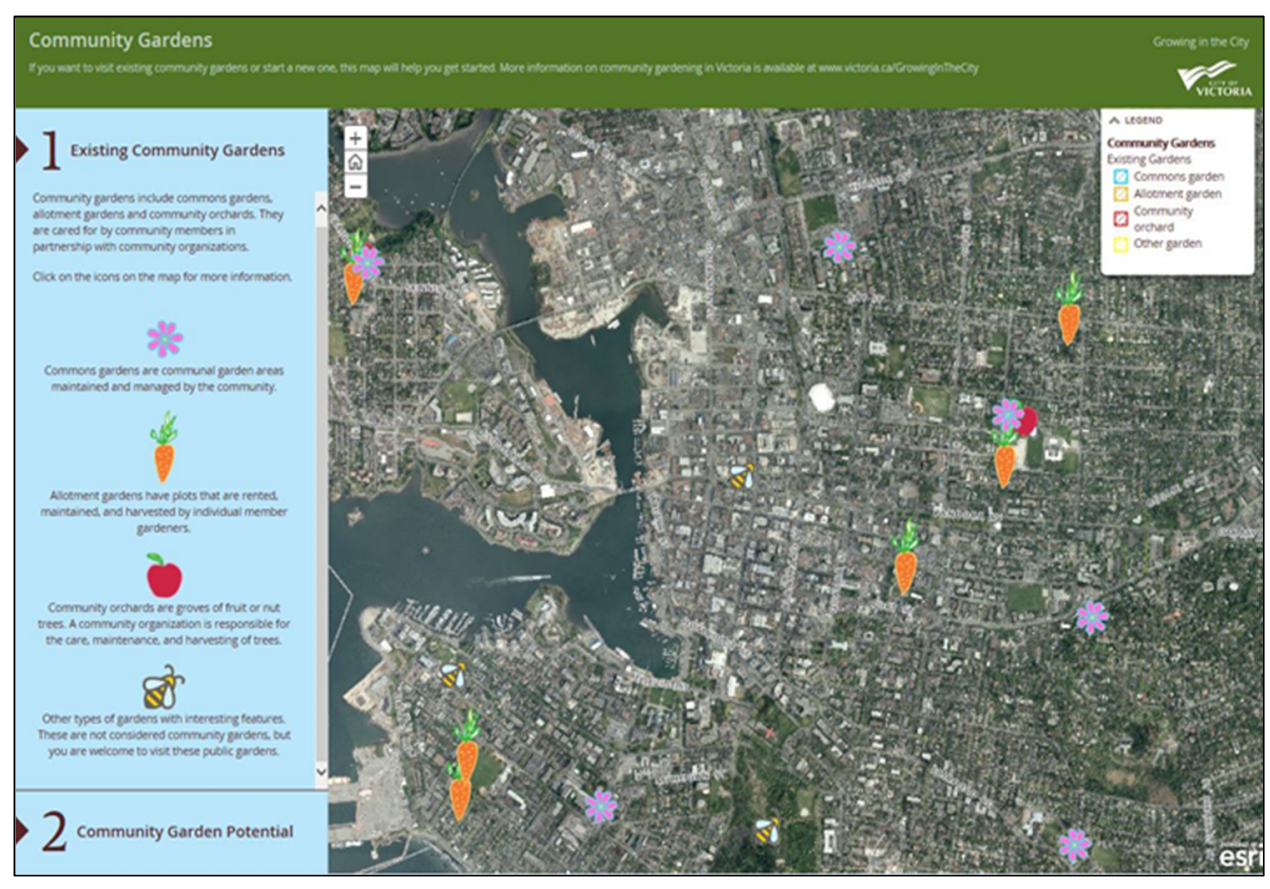

Figure 3. VicM ap Inventory of City-owned Land with Community Gardening Potential

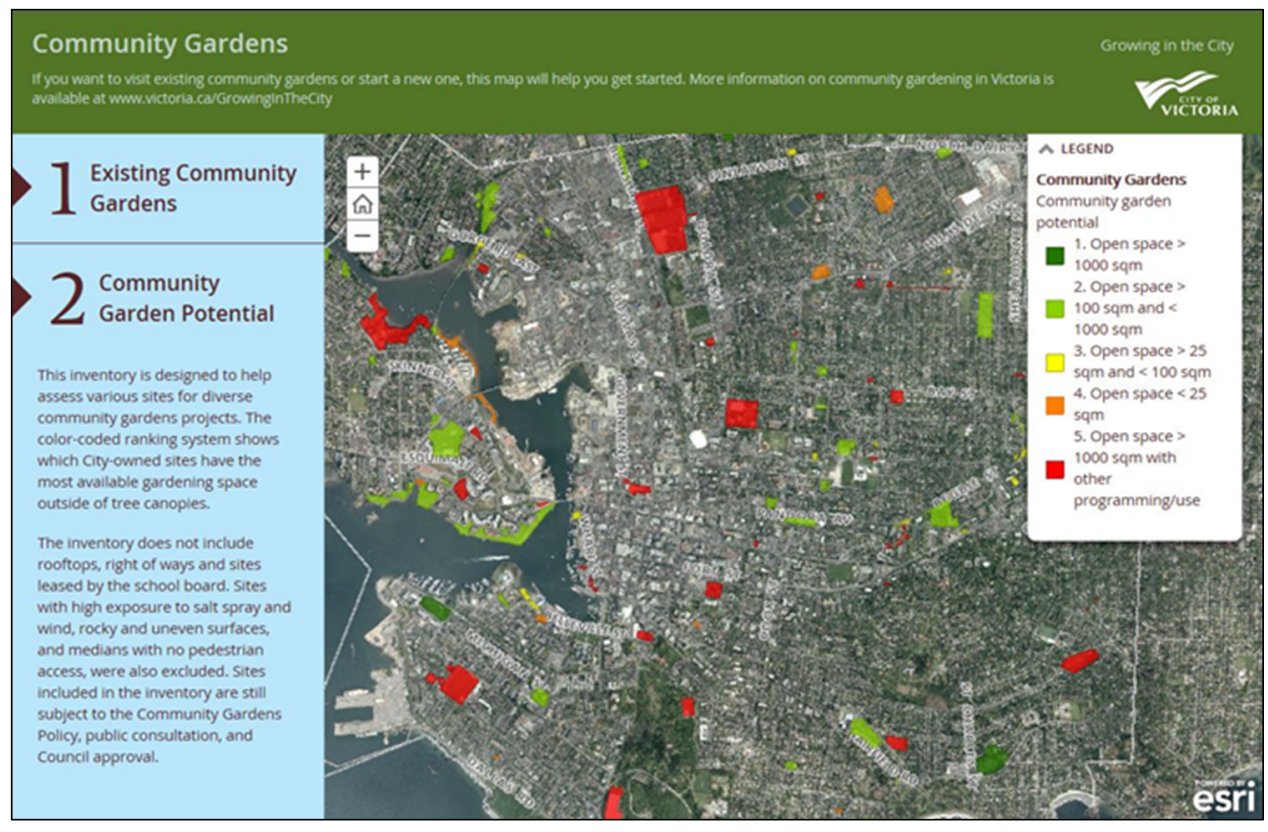

interest to residents.

- Remove the ability to restrict garden membership by neighborhood of residence. City-owned land with gardening potential is not equally distributed throughout neighborhoods.

- Increase staff support for new community garden projects to assist project proponents.

- Simplify the application process for new community gardens and provide better alignment with the city's grant application deadlines.

- Provide in-kind support, including excess leaf mulch and the waiving of water charges for all community gardens, as well as installation of split-rail fencing and a municipal water hook-up for new gardens on cityowned lands.

Inventory of City-owned $\mathrm{L}$ and for $\mathrm{C}$ ommunity $\mathrm{G}$ ardening To help residents identify and assess sites for community gardening, the muni-

Based on citizen feedback, the 2003 Community Gardens Policy was revised in 2016 (City of Victoria, 2016e) to:

- Expand the definition of community gardens to better reflect the wide range of activities of cipality developed an inventory of city-owned land with community gardening potential (see Figure 3). A ranking system shows which city-owned sites have the most available open space. The inventory considered all properties owned by the city, including both pervious and impervious surfaces, 
but excluding roof tops, rights-of-way, lands leased to the school board, lands with highly unfavorable growing conditions, and road medians with no pedestrian access. Sites included in the inventory are still subject to the community gardens policy and Council approval. The inventory is available on the Community Gardens Map on the city's interactive mapping system, VicMap (http:/ / vicmap. victoria.ca/ CommunityG ardens).

\section{Urban F ood Tree Stewardship Pilot Program} Community feedback showed strong public interest for planting food trees on city boulevards and other green spaces. However, food-bearing trees grown in public spaces also present potential challenges, including intensive maintenance requirements, harvest management and safety, and allergy concerns. Fallen fruits may attract pests and rodents, damage property, or present a slipping or tripping hazard. G ITC introduced the "Urban Food Tree Stewardship Program" in 2016, a five-year pilot program to expand the number of fruit and nut trees planted in the city while recognizing and mitigating the associated challenges. Residents can apply to plant and maintain up to five food trees in a park or open space through a partnership agreement between a community organization and Parks. Community food tree stewards are responsible for selecting, purchasing, maintaining, watering, and harvesting the tree(s). Parks assists with tree planting. Figure 4 shows a photo of the first planting.

Figure 5. Food-producing Container Beds on a City Boulevard with Sidewalk

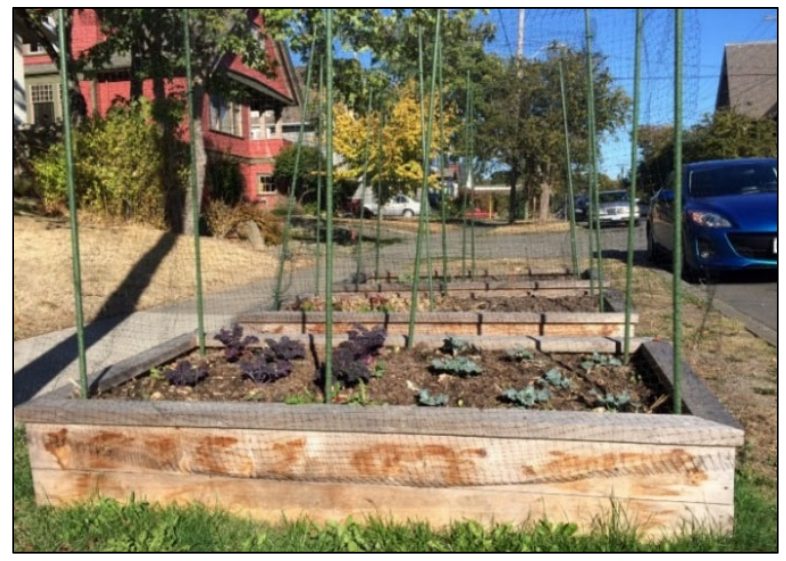

Boulevard $\mathrm{G}$ ardening $\mathrm{G}$ uidelines

G enerally speaking, boulevards are the strip of city-owned land between a property and the street. Boulevard gardens (replacing the traditional grass boulevard with other plants) have been appearing informally on City of Victoria boulevards for a number of years. Figures 5 and 6 show examples of boulevard gardens. In 2014, a citizen-led initiative resulted in a one-year pilot project to support and guide the creation of these garden beds on boulevards fronting residential lots, based on an interim set of Boulevard Gardening Guidelines. GITC consultations indicated that boulevard gardens were generally supported across the city and that residents perceive the gardens to build neighborhood character, make sidewalks more interesting, provide more space to garden, and

Figure 4. The First Apple Tree Being Planted under the Urban Food Tree Stewardship Pilot Program

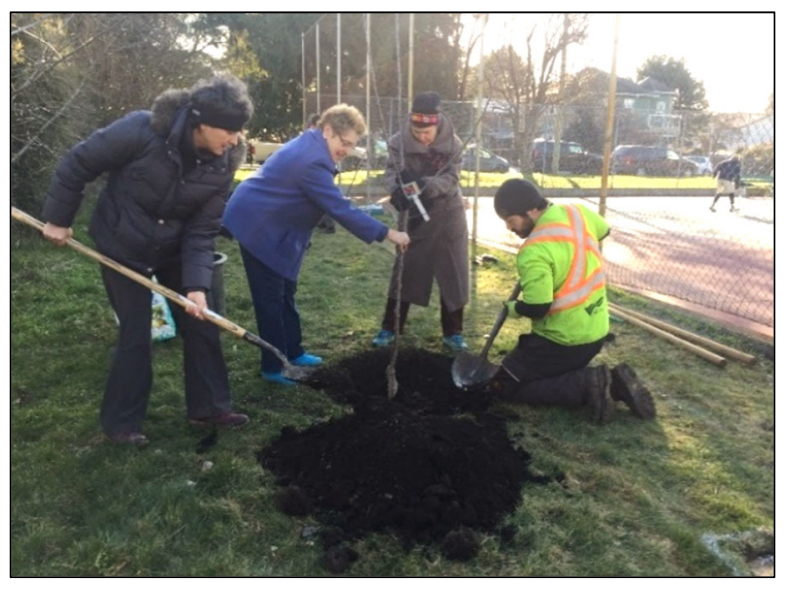

Figure 6. Boulevard Garden beside a Retaining Wall Planted with Winter Squash and Tomato

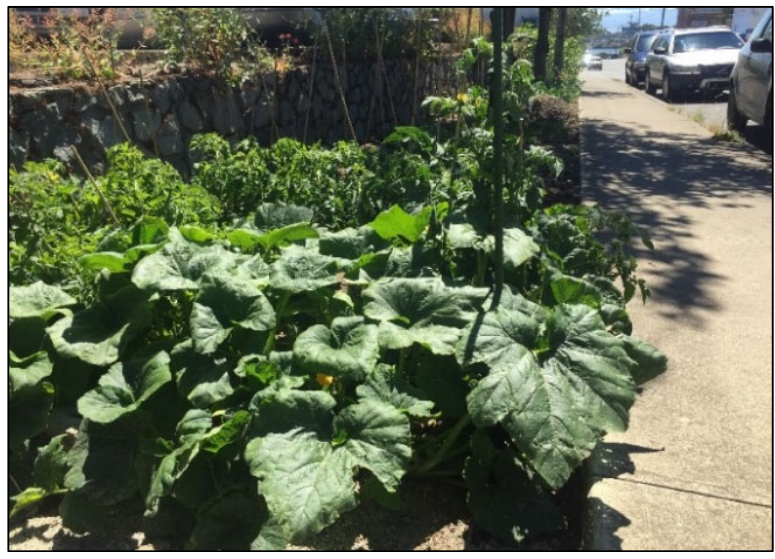


provide beneficial habitat for pollinators and wildlife. Because boulevard gardens can be perceived as being messy or unkempt, site aesthetics were a primary concern. The final Boulevard Gardening G uidelines (City of Victoria, 2016b) introduced as part of GITC were revised to add a mechanism to deal with abandoned or unsafe gardens. The Streets and Traffic Bylaw (City of Victoria, 2016k) was also amended in 2016 to allow boulevard gardening and to specify design, safety and maintenance requirements.

Regulatory A mendments to Support Small-scale Commercial U rban F ood Production (G IT C Part 2) Commercial urban food production, which produces agricultural products for sale in the city, is an emerging use, but one that does not fit neatly into zoning or other city regulations. Victoria is one of the first Canadian municipalities to tackle the emerging topic of commercial urban agriculture by adopting new regulations that enable the growing and selling of food in the city, with limits to minimize negative impacts on neighboring properties.

D rawing on the results of public engagement, a series of bylaw amendments were proposed to support commercial urban food production on a scale that is compatible with other urban land uses, particularly in residential and commercial areas. These amendments were developed to allow small-scale commercial enterprises to operate and also to allow "hobby producers" to sell surpluses from their home gardens.

GITC engagement indicated that $87 \%$ of respondents supported small-scale urban agriculture activities in their neighborhood. Many survey respondents connected increased commercial urban food production with food security, education, and the provision of local economic opportunities. For example:

The closer the food is grown and the more diverse the gardening, the stronger is our food security and the more likely it is to be sustainable. (City of Victoria, 2016h)

People who are doing this good work need more ways to get paid for their work, i.e., more opportunities to sell their produce.
And it's good for others to be able to see (and buy) the produce right where it is grown. (City of Victoria, 2016h)

Some public concerns about these activities included noise (from machinery and deliveries), hours of operations, odors (from compost, soil amendments, or chickens), parking for customers and employees, artificial greenhouse lighting, increased pesticide and synthetic fertilizer use, and site aesthetics and maintenance, as well as compatibility of agricultural uses in residential areas. The following are comments from survey respondents who did not support urban food production becoming recognized as a use in the city's zoning bylaw.

The commercial garden acceptability depends on where it is situated and who may be impacted. This is a land use matter and each should require full land-use system approval. So much depends on the expertise of the gardener, and the impacts on others... (City of Victoria, 2016h)

Prioritise residential development to reduce pressure on housing costs, not so that a small number of people can make money growing food in a cost-inefficient and unsustainable way. Food simply doesn't need to be produced in the city of Victoria, it is done far more sustainably in surrounding farmland. (City of Victoria, 2016h)

D efining Small-scale Commercial U rban F ood Production in the Z oning Regulation Bylaw As part of GITC, the Zoning Regulation Bylaw (City of Victoria, n.d.-b) was amended in 2016 to define "small-scale commercial urban food production" to include the cultivation, harvesting, keeping, sorting, cleaning, and packaging of the following edible and non-edible products: raw and unprocessed fruits, vegetables and mushrooms, flowers, herbs, fiber, seeds, nuts, seedlings, plant cuttings, eggs, and honey. This new definition addresses previous restriction on the sale of animal products (e.g., eggs and honey) and expands allowed products to non-edible crops. The 
definition also excludes products regulated by the Controlled D rug and Substances Act and the sale of value-added food products (e.g., jams, bread or prepared meals).

\section{A llowing Small-scale Commercial U rban F ood Production in A ll Zones}

In 2008 the city introduced "urban agriculture" as a home occupation under its Zoning Regulation Bylaw (City of Victoria, n.d.-b), which allowed up to two people living on site to produce fruits and vegetables for retail purposes on a portion of the parcel. As with other home occupations, retail sales were not allowed from the site. Urban farmers wanting to establish a commercial urban agriculture operation away from their place of residence were directed to industrial areas. Through G ITC consultations, urban producers indicated they would prefer not to be limited to industrial areas due to the limited availability of arable land, risk of soil contamination, and limitations on retail sales. To expand the range of potential sites for new and existing urban farms to include commercial areas, vacant residential lots, rooftops, institutional properties, and other underused sites, the Zoning Regulation Bylaw (City of Victoria, n.d.-b) was amended in 2016 to permit "small-scale commercial urban food production" in all zones, provided it does not create noxious or offensive odors, noise and light pollution. "Urban Agriculture" was removed from the definition of "home occupation" to allow more flexibility for lands to be used for urban food production.

$0 \mathrm{n}$-site and $0 \mathrm{ff}$-site Sales of U rban F ood Products

There was strong interest from the community and urban producers for on-site sales, but several regulatory barriers limited them.
As part of GITC, the Zoning Regulation Bylaw (City of Victoria, n.d.-b) was amended in 2016 to allow food stands in all zones. O nly products grown on-site can be sold at a food stand, and food stand sales are limited to products identified in the definition of small-scale commercial urban food production. The bylaw also identifies permitted food stand hours of operations and maximum size, as well as placement and setback requirements (illustrated in Figure 7). Food stands cannot be fully enclosed and can be made of tables, baskets, bins, or shelves. They do not require a building permit. As part of GITC, the Business Licence Bylaw (City of Victoria, 2015b) was amended to introduce a new business licence category. An annual (CA \$100) and a three-month (CA \$25) business licence are now available for food stands or other on-site sales at permitted locations such as restaurants and grocery stores.

The off-site retail sale of commercial urban food products is also allowed in all zones. An annual business licence (CA $\$ 100)$ for off-site retail sales is also available. Examples of off-site sales include farmers markets, retailers, restaurants, box programs, and other private sales.

\section{E x emptions for R ooftop G reenhouses}

Rooftop greenhouses can enable year-round local food production. Where buildings have the structural capacity to support a rooftop greenhouse,
Figure 7. Diagram Showing Permitted Food Stand Dimension and Location

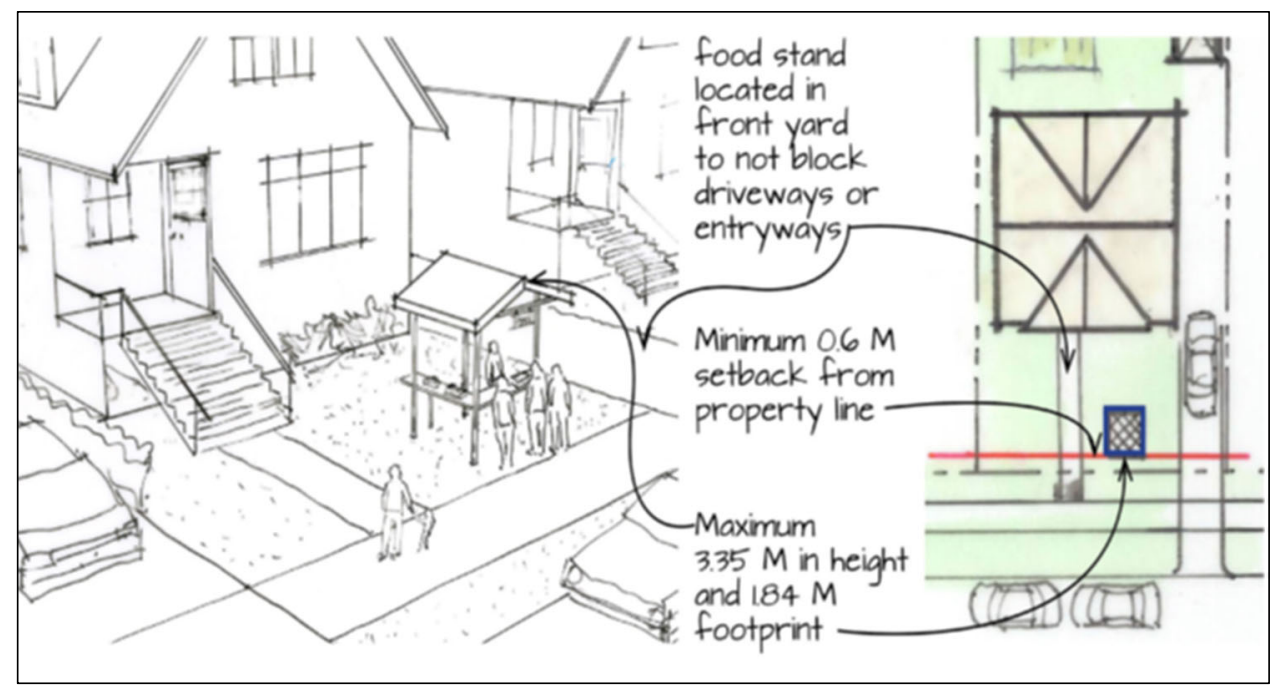


zoning regulations for building height and floor area have constrained opportunities for rooftop greenhouses. To encourage small rooftop greenhouses, the Zoning Regulation Bylaw (City of Victoria, n.d.-b) was amended in 2016 as part of GITC to permit rooftop greenhouses on multi-unit developments such as apartment buildings with at least four units. Rooftop greenhouses are not permitted in low-density residential zones or on smaller multi-unit developments with fewer than four units.

As a result of GITC, rooftop greenhouses are also excluded from zoning height calculations and floor space ratio calculations, provided they meet specific dimension requirements. To minimize visual impacts on neighbors and the public realm, only small greenhouses measuring up to 3.65 meters (12 feet) in height and 28 square meters (301 square feet) or no more than $50 \%$ of the building area (whichever is less) are excluded from zoning height calculations and floor space ratio calculations. As a result of the 2016 amendment, greenhouses are defined as a structure made of glass or other translucent materials used for the cultivation or protection of plants, and can be used for personal, community, educational, or business purposes.

\section{Restrict the U se of Pesticides in Commercial} U rban F ood Production

One of the key concerns expressed by the community and Council was the potential use of pesticides for increased urban food production. The existing Pesticide Reduction Bylaw (City of Victoria, n.d.-a) was amended in 2016 as part of GITC to restrict the application of pesticides in small-scale commercial urban food production. Only pesticides on the provincial list of reduced-risk, permitted pesticides ${ }^{3}$ can be used for small-scale commercial urban food production, unless a permit is obtained.

\section{Implementation and $\mathrm{O}$ utreach}

Following the adoption of revised policies, guidelines and regulations, the final phase of G ITC focused on implementation and community outreach. In 2015, a full-time food systems coordinator position was created in the Parks department. The city's food systems coordinator also attends monthly meetings of the Urban Food Table and is a member of the CRD Regional Food and Agriculture Task Force.

From the beginning, municipal staff recognized the importance of good quality communications and educational materials to support the implementation of GITC initiatives. Outreach was directed at both city staff and the community. Educational materials were developed for the public and made available on the city's one-stop web portal for urban food and gardening (https:/ / www.victoria.ca/ growinginthecity). To support the delivery of city services, summaries of the new urban food regulations were developed for internal use only. Staff meetings provided opportunities to coordinate program delivery to align with existing city operations.

Education materials that support urban food production in the public realm include fact sheets to aid new and expert gardeners (City of Victoria, 2016a; 2016b; 2016c; 2016l). Materials developed to support commercial urban food production (City of Victoria, 2016d; 2016i; 2016j; 2017b) include a handbook and fact sheets, which are available at https:/ / www.victoria.ca/ foodpro duction. City staff also participate in public food and gardening events, and submit information to community newsletters. City-led workshops are being developed to continue dissemination and increase general uptake.

\section{Discussion}

\section{Sucoesses}

The impacts of the new policies, programs, and bylaws are being monitored. It is too early to evaluate the extent to which GITC initiatives are having the intended impact of increasing opportunities for urban food production. Nonetheless, the increase in the number of community gardens, boulevard gardens, and food trees being planted in the city indicate a strong and possibly growing community

${ }^{3}$ The provincial list of reduced-risk, permitted pesticides can be found at

https:/ / www.victoria.ca/ EN/ main/ residents/ parks/ natural-areas/ pesticide-reduction.html 
interest in diverse community gardening projects (see Table 2).

Key factors that explain success include:

- The long-standing active engagement of knowledgable community members and organizations to deliver programs and services and bring forward new projects.

- Constant support from City Council, who identified enhancing food systems as an objective in the 2015-2018 Strategic Plan, voted in favor of the GITC changes, approved proposals for new community gardens, and awarded grants to organizations involved in food systems work.

- Ongoing inter- and intradepartmental collaboration among city staff who worked closely on the GITC consultation process, development of the policies and programs, and creation of resources to implement the GITC changes.

- City grants support different types of community gardening projects, ranging from coordinating community garden volunteers to building a toolshed. From 2016 to 2018 the city awarded approximately CA $\$ 120,000$ through the community garden volunteer coordinator grants. A total of CA $\$ 12,000$ was awarded in microgrants for community gardening from 2015 to 2018. Place-making grants, the participatory budgeting process grants, and the strategic plan grants are other granting streams with broader scope that have supported urban food and gardening projects and organizations. Of the available CA $\$ 52,500$, the participatory budgeting process awarded a total of CA $\$ 27,500$ to two urban food and gardening projects.

- Recent informal conversations with urban farmers indicate that consumer demand for city-grown food is reportedly high, with local restaurants playing a key role in supporting urban farming businesses.

\section{Challenges: C ommercial U rban F ood Production}

Balancing visual appeal and safety with farmer needs Although the feedback obtained through the G ITC consultation resulted in multiple changes in city regulations, the city was not in the position to address all regulatory issues or implement all suggestions. For example, urban farmers identified as a barrier to expanded commercial urban food production the need for a development permit for structures such as greenhouses and walk-in coolers in applicable areas. Because these permits serve important purposes in regulating visual impacts from adjacent properties and the public realm, buildings and structures associated with commercial urban food continue to require development permits. Urban farmers also identified as a barrier the need for a building permit for agriculturerelated buildings and structures, particularly for temporary plastic hoop houses. The city continues to require a building permit for agriculture-related buildings and structures due to the safety risks posed by permanent and temporary structures (e.g., collapsing from the weight of snow, or materials blowing around in strong winds).

Table 2. Number of New Community Gardens, Food Trees, Boulevard Gardens, Business Licences, and Rooftop Greenhouse since February 2016

\begin{tabular}{ll}
\hline Community gardens & 1 allotmenta and 2 commons with pollinator and native plantings \\
\hline Food trees on city land & 10 apple and hazelnut trees \\
\hline Boulevard gardens & Present in all 13 neighborhoods of the city. Number unknown. \\
\hline Business licences & 10 licences approved; most producers grow vegetables \\
\hline Rooftop greenhouses & No rooftop greenhouses proposed as of June 2018 \\
\hline $\begin{array}{l}\text { a The allotment garden in contained raised beds on the former site of a dry-cleaning business, now a remediated city-owned property. The } \\
\text { project was initiated through Citystudio Victoria, an innovation hub for staff, university students and community members. }\end{array}$
\end{tabular}


Mitigating tax burden from farm dassification

Some urban farmers encouraged the city to adopt lower tax rates and create incentives for more commencial urban food production. In British Columbia, properties under 8,000 square meters $(86,111$ square feet) with farm sales exceeding CA $\$ 10,000$ can be classified as a farm-class property by the $\mathrm{BC}$ Assessment Authority. The assessment value is typically lower for farm-class property, so owners of farm properties typically pay less taxes. However, in 2008, Council directed staff to amend the city's revenue and tax policy so that farm-class properties pay equivalent taxes to residential-class properties. This policy was introduced to mitigate the potential increase in tax burden to existing tax classes with commercial urban agriculture being added to the list of permitted home occupations. The city maintains the current policy with respect to farm-class tax rates.

$\mathrm{N}$ on-regulatory barriers Other barriers identified by urban farmers include the insecurity of land tenure, lack of economic viability of urban farming, lack of preferential water pricing for urban farms, and need for more skills training and access to capital for new farmers. These nonregulatory barriers were outside the scope of the GITC project.

\section{Balancing housing needs and food production} It is difficult to gauge future interest in commercial urban food production. How the city will balance its growth targets for new housing and development with urban agriculture may be negotiated on case-bycase basis. The following quote from a survey respondent illustrates the potential for tension between commercial urban farming and the need for more housing:

I don't think urban agriculture should be prioritised over residential living... .There may be a time when an urban agriculture business conflicts with downtown living; at that point I think residential development should trump small-scale agriculture. (City of Victoria, 2015d)
New developments, however, might also present unique and innovative opportunities to integrate commercial urban food production to the built form. For example, in New York, the Staten Island development Urby hires two farmers-in-residence who grow produce in a 5,000-square-foot (465-square-meter) courtyard, keep honey bees on rooftops, and operate an onsite food stand (Rosen, 2017). Lots left empty as they await development also have the potential to host commercial urban food production. For example, the Victoria-based urban agriculture business TO PSOIL (see Figure 8) is located on a 1,400-square-meter (15,000-square-foot) temporarily vacant lot at $\mathrm{D}$ ockside $\mathrm{G}$ reen, a development project in the Victoria West neighborhood.

\section{Challenges: C ommunity F ood Production} in the Public Realm

\section{L imited land base}

Challenges for starting new community gardens include Victoria's limited land base and a sometimes conflicting community desire for more natural areas and unprogrammed open spaces. At the same time, the increasing urban density and the

Figure 8. The Urban Agriculture Business TOPSOIL, Located on a Temporarily Vacant Lot at Dockside Green, Victoria, British Columbia

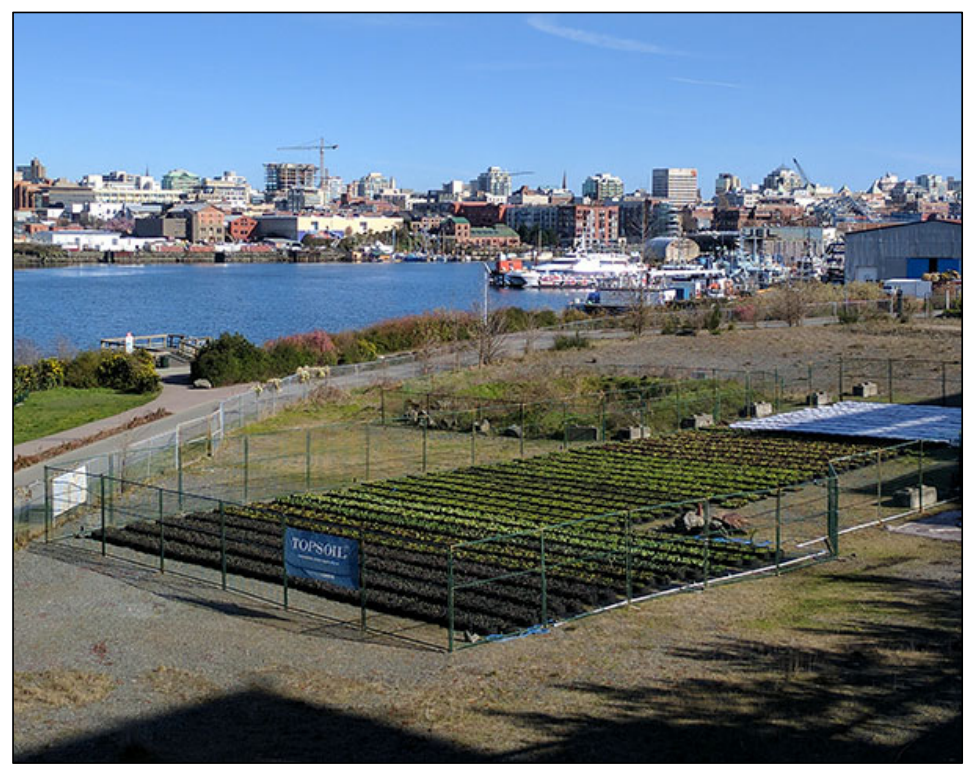


disappearance of private gardening spaces drive further demand for community gardens.

Capacity for the community garden start-up phase The process of developing a proposal for a new community garden is demanding and is led primarily by volunteers. The city does not build or maintain community gardens, and currently there is no city funding that supports the community garden planning stage.

A llotment gardens perœived as ex dusive use of public spaœ Allotment gardens may be perceived as an inappropriate use of public space. Although there are 18 community gardens in the city (seven allotment gardens, nine commons gardens, and two community orchards), two neighborhoods do not have a community garden, and eight of 13 neighborhoods do not have an allotment garden. O ne survey respondent noted that allotment gardens are an exclusive use of public space:

Totally against allotment gardens in public parks. There can be no justification for giving individuals exclusive, open ended access to public land. (City of Victoria, 2015d)

New developments are also perceived as opportunities for increasing the number of allotment plots. O ne survey respondent asked the city to:

Encourage incorporation of tenant's plot in new developments, and explore ways of encouraging conversion of some existing (apartment) lawns to allotment areas for tenants. It doesn't all have to be done on city land... (City of Victoria, 2015d)

Key L essons

Community engagement is key in identifying which policy and programs enable urban food production. For example, through in-depth engagement, the city became aware of the context in which urban farming typically occurs and how specific regulations hindered urban farming. D etermining factors such as strong community involvement, small profit margins, zoning limitations and where products are sold were brought to the attention of the city through the participation of urban farmers. The policy changes are, in many ways, a direct reflection of some of their feedback.

Communication and collaboration are key in urban food policy. The process of converting community input into new policies, regulations, and programs, and the process of rolling out these changes both internally and externally, cut across multiple departments. In the short term, the creation of resources for city staff and the public helped communicate the impact of the changes and the opportunities they present. In the long term, the emergence of an environment where urban food production is fully embraced as part of the urban fabric is expected to require ongoing communication and collaboration.

Ensuring that the community has the capacity to benefit from the GITC changes and increase community gardening and urban food production in the public realm may require further support from the city. Because new projects on city land are usually led by volunteers, supportive policies and information may not be enough to have a significant impact on, for example, increasing the number of allotment gardens. Capital investments or funding for the convening, designing, and building phases of new community gardens are avenues that could be considered. At the same time, additional city involvement should not dilute or undermine community ownership of community gardening projects.

\section{Conclusion}

Building on a strong foundation of support from the community and City Council, the GITC project aimed to reduce barriers to urban gardening and food production through a variety of policy, educational, and regulatory mechanisms.

The GITC project grew out of a recognition that urban food production and gardening are rapidly evolving to encompass a broad set of activities that go beyond the "traditional" allotment garden. Commons gardens, boulevard gardening, and stewarding food trees in city greenspaces are gaining in popularity and are increasingly being used as community-building and place-making activities. While food production is an important focus for many, a growing number of residents 
Journal of Agriculture, Food Systems, and Community D evelopment

ISSN: 2152-0801 online

https:/ / www.foodsystemsjournal.org

garden to beautify and animate public spaces and to support biodiversity. Through a suite of updated and new programs, the GITC project aimed to make it easier for residents to participate in gardening on public lands.

The rise of local food movements has supported a growing interest in urban agriculture activities, ranging from sharing food with neighbors through food-stand sales, to supplying regular deliveries to local restaurants. Through the new urban food bylaws and the availability of educational materials, the City of Victoria is committed to enabling small-scale commercial urban food production. The modest uptake in the first years may be due to the very recent introduction of the new regulations, systemic issues affecting the food and agriculture sector, remaining regulatory restrictions, or other unknown barriers.

As the new programs, policies, and regulations are implemented, both successes and challenges are emerging. Ongoing monitoring will be required to assess the positive impact of these changes, and to adapt regulations and policies to the rapidly changing landscape of urban gardening and food production in the private and public realms.

\section{References}

Armstrong, D. (2000). A survey of community gardens in upstate New Y ork: Implications for health promotion and community development. H ealth \& Plaœ, 6(4), 319-327. https:/ / doi.org/ 10.1016/ S1353-8292(00)00013-7

Butler, W. H. (2012). Welcoming animals back to the city: Navigating the tensions of urban livestock through municipal ordinances. Journal of A grialture, Food Systems and Community D evelopment, 2(2), 193-215. https:/ / dx.doi.org/ 10.5304/ jafscd.2012.022.003

Canada Mortgage and Housing Corporation. (2015). Rental mark et report V ictoria CMA . Retrieved from https:/ / eppdscrmssa01.blob.core.windows.net/ cmhcprodcontainer/ sf/ project/ cmhc/ pubsandreports/ esub/ all e sub pdfs/ 644712015 a01.pdf?sv=2017-07-29\&ss=b\&sit=sco\&sp=r\&se=2019-05-09T06:10:51Z \&st=2018-0311T22:10:51Z\&spr=https,http\&sig=0K etq0sPG tnokWO e66BpqguD ljV gBRH 9wLO Cg8H fE 3w\%3D

Capital Regional District. (2016). Setting our table: Capital Regional D istrid food and agrialture strategy. Capital Regional District. Retrieved from http:/ / www.crd.bc.ca/ docs/ default-source/ regional-planning-pdf/ food-agriculture/ draftregional-food-agriculture-strategy-web.pdf?sfvisn $=4$

City of Victoria. (n.d.-a). Pesticide use reduction bylaw (No. 07-094). Retrieved from https:/ / www.victoria.ca/ assets/ City Hall/ Bylaws/ bylaw-07-094.pdf

City of Victoria. (n.d.-b). Z oning regulation bylaw (No. 80-159). Retrieved from https:/ www.victoria.ca/ EN/ main/ residents/ planning-development/ development-services/ zoning/ zoningregulation-bylaw.html

City of Victoria. (2012). 0 fffical Community Plan Bylaw. Retrieved from https:/ / www.victoria.ca/ assets/ Departments/ Planning D evelopment/ Community Planning/ OCP/ Replaced/ O CP Book 2012 amended Sept 2016.pdf

City of Victoria. (2015a, January). A nimal control bylaw (No. 11-044, Consolidated). Retrieved from https:/ / www.victoria.ca/ assets/ City Hall/ Bylaws/ bylaw-11-044.pdf

City of Victoria. (2015b). Business lioence bylaw (No. 89-071, Consolidated). Retrieved from https:/ / www.victoria.ca/ assets/ City Hall/ Bylaws/ Business Licence Bylaw 89-071 (consolidated).pdf

City of Victoria. (2015c). City of V ictoria strategic plan 2015-2018. Retrieved from https:// www.victoria.ca/ assets/ City Hall/ D ocuments/ Strategic Plan 2015-2018.pdf

City of Victoria. (2015d). Phase one: Community feedbadk report. Retrieved from https:/ / pubvictoria.escribemeetings.com/ filestream. ash $x$ ?documentid $=14594$

City of Victoria. (2016a). B oulevard gardening fact sheet. Retrieved from https:/ / www.victoria.ca/ assets/ D epartments/ Parks Rec Culture/ Parks/ D ocuments/Boulevard\%20G ardening e.pdf

City of Victoria. (2016b). Boulevard gardening guidelines. Retrieved from https:/ / www.victoria.ca/ assets/ D epartments/ Parks Rec Culture/ Parks/ D ocuments/ Boulevard G ardening G uidelines e.pdf

City of Victoria. (2016c). Building a community garden on city land. Retrieved from https:// www.victoria.ca/ assets/ Departments/ Parks Rec Culture/ Parks/ D ocuments/G rowing in the City/ Building a Community G arden.pdf 
City of Victoria. (2016d). Building a roottop greenhouse. Retrieved from https:/ / www.victoria.ca/ assets/ D epartments/ Parks Rec Culture/ Parks/D ocuments/G rowing in the City/ Building Rooftop G reenhouse.pdf

City of Victoria. (2016e). Community gardens policy. Retrieved from https:/ / www.victoria.ca/ assets/ Community/ Growing in the City/Community Gardens Policy_Revised 2016.pdf

City of Victoria. (2016f). G rowing in the city - Part 1: U rban food production on aty-owned lands. Retrieved from https:/ / pubvictoria.escribemeetings.com/ filestream.ashx?documentid $=14593$

City of Victoria. (2016g). G rowing in the city - Part 2: Regulatory amendments to support small-scale commercial urban farming. Retrieved from https:/ / pub-victoria.escribemeetings.com/ filestream.ashx?documentid=14602

City of Victoria. (2016h). G rowing in the aity: Phase two: Community feedback report. Retrieved from https:/ / pubvictoria.escribemeetings.com/ filestream.ashx?documentid $=14595$

City of Victoria. (2016i). Small-scale commercial urban food production handbook. Retrieved from https:// www.victoria.ca/ assets/ D epartments/ Parks Rec Culture/ Parks/Documents/Growing in the City/ Sm all Scale Commercial Urban Food Production Handbook.pdf

City of Victoria. (2016j). Starting a small-scale urban food production business in the City of $\mathrm{V}$ ictoria. Retrieved from https:/ / www.victoria.ca/ assets/ Business/ D ocuments/ Urban Food Fact Sheet.pdf

City of Victoria. (2016k). Streets and traffic bylaw (No.09-079, Consolidated). Retrieved from https:/ / www.victoria.ca/ assets/ D efault/ Streets and Traffic Bylaw 09-079 (consolidated).pdf

City of Victoria. (2016l). U rban food tree stewardship pilot program. Retrieved from https:/ / www.victoria.ca/ assets/ D epartments/ Parks Rec Culture/ Parks/ D ocuments/Urban Food Tree Steward Pilot Program.pdf

City of Victoria. (2016m). V ictoria housing strategy 2016-2025. Retrieved from https:/ / www.victoria.ca/ assets/ D epartments/ Planning D evelopment/ Community Planning/ D ocuments/Victoria Housing Strategy Final June 2016.pdf

City of Victoria. (2017a). Parks and open spaœ master plan. Retrieved from https:/ / www.victoria.ca/ assets/ Departments/ Parks Rec Culture/ Parks/ Parks and Open Spaces Master Plan May 2017.pdf

City of Victoria. (2017b). Building and operating a food stand. Retrieved from https:/ / www.victoria.ca/ assets/ D epartments/ Parks Rec C Culture/ Parks/D ocuments/G rowing in the City/ Building and O perating a Food Stand June 2017.pdf

de la Salle, J., \& Holland, M. (Eds.). (2010). A grialtural urbanism: H andbook for building sustainable food \& agriculture systems in 21 st century cities. Winnipeg, Manitoba: Green Frigate Books.

Draper, C., \& Freedman, D . (2010). Review and analysis of the benefits, purposes, and motivations associated with community gardening in the United States. Journal of Community Practiœ, 18(4), 458-492. https:/ / doi.org/ 10.1080/ 10705422.2010.519682

Ferris, J., Norman, C., \& Sempik, J. (2001). People, land and sustainability: Community gardens and the social dimension of sustainable development. Social Policy \& A dministration, 35(5), 559-568. https:/ / doi.org/ 10.1111/ 1467-9515.t01-1$\underline{00253}$

Hodgson, K., AICP, Campbell, M. C., \& Bailkey, M. (2011). U rban agriculture: G rowing healthy, sustainable places (PAS Report No. 563). Chicago, Illinois: APA Planning Advisory Service.

MacRae, R., G allant, E., Patel, S., Michalak, M., Bunch, M., \& Schaffner, S. (2010). Could Toronto provide 10\% of its fresh vegetable requirements from within its own boundaries? Matching consumption requirements with growing spaces. Journal of A griculture, Food Systems, and Community D evelopment, 1(2), 105-127. https:// doi.org/ 10.5304/ jafscd.2010.012.008

MacRae, R., Nasr, J., Kuhns, J., Baker, L., Christianson, R., D anyluk, M.,... Wekerle, G . (2012). Could Toronto provide $10 \%$ of its fresh vegetables requirements from withing its own boundaries? Part II, Policy supports and program design. Journal of A griaulture, F ood Systems and Community D evelopment, 2(2), 147-169. https:// doi.org/ 10.5304/ jafscd.2012.022.002

Mansfield, B., \& Mendes, W. (2013). Municipal food strategies and integrated approaches to urban agriculture: Exploring three cases from the global north. International Planning Studies, 18(1), 37-60.

https:/ / doi.org/ 10.1080/ 13563475.2013.750942 
Journal of Agriculture, Food Systems, and Community Development

ISSN: 2152-0801 online

https:/ / www.foodsystemsjournal.org

McClintock, N., Wooten, H., \& Brown, A. H. (2012). Toward a food policy "first step" in O akland, California: A food policy council's efforts to promote urban agriculture zoning. Journal of A griaulture, Food Systems and Community D evelopment, 2(4), 15-24. https:/ / doi.org/ 10.5304/ jafscd.2012.024.009

Mendes, W., Balmer, K., Kaethler, T., \& Rhoads, A. (2008). Using land inventories to plan for urban agriculture: Experiences from Portland and Vancouver. Journal of the A merican Planning A ssociation, 74(4), 435-449. https:/ / doi.org/ 10.1080/ 01944360802354923

Morgan, K. (2009). Feeding the city: The challenge of urban food planning. International Planning Studies, 14(4), 341-348. https:/ / doi.org/ 10.1080/ 13563471003642852

Morgan, K. (2013). The rise of urban food planning. International Planning Studies, 18(1), 1-4. https:/ / doi.org/ 10.1080/ 13563475.2012.752189

Morgan, K., \& Sonnino, R. (2010). The urban foodscape: World cities and the new food equation. Cambridge Journal of Regions, E conomy and Society, 3(2), 209-224. https:// doi.org/ 10.1093/ cjres/ rsq007

Pothukuchi, K., \& Kaufman, J. L. (1999). Placing the food system on the urban agend: The role of municipal institutions in food systems planning. A griculture and H uman V alues, 16(2), 213-244. https:/ / doi.org/ 10.1023/ A:1007558805953

Pothukuchi, K., \& Kaufman, J. L. (2000). The food system: A stranger to the planning field. Journal of the A merican Planning A ssociation, 66(2), 113-124. https:/ / doi.org/ 10.1080/ 01944360008976093

Rosen, K. R. (2017, March 10). A Staten Island urban farmer. The N ew Y ork Times. Retrieved from https:/ / www.nytimes.com/ 2017/ 03/ 10/ realestate/ a-staten-island-urban-farmer.html

Soma, T., \& Wakefield, S. (2011). The emerging role of a food system planner: Integrating food considerations into planning. Journal of A griaulture, F ood Systems, and C ommunity D evelopment, 2(1), 53-64. https:/ / doi.org/ 10.5304/ jafscd.2011.021.006

Sonnino, R. (2009). Feeding the city: Towards a new research and planning agenda. International Planning Studies, 14(4), 425-435. https:/ / doi.org/ 10.1080/ 13563471003642795

Statistics Canada. (2016a). F arm operators dassified by number of operators per farm and age (Table No. 32-10-0442-01) [Table]. Retrieved from https:/ / www150.statcan.gc.ca/ t1/ tbl1/ en/ tv.action?pid=3210044201

Statistics Canada. (2016b). Tenure of land owned, leased, rented, crop-shared, used through other arrangements or used by others (Table No. 32-10-0407-01) [Table]. Retrieved from https:/ / www150.statcan.gc.ca/ t1/ tbl1/ en/ tv.action?pid=3210040701

Statistics Canada. (2016c). Total number of farms and farm operators (Table No. 32-10-0440-01) [Table]. Retrieved from https:/ / www150.statcan.gc.ca/ t1/ tbl1/ en/ tv.action?pid=3210044001

Statistics Canada. (2017a). Census profile, 2016 Census: Victoria, city [Census subdivision], British Columbia and capital, regional district [Census division], British Columbia [Table]. Retrieved from http:/ / www12.statcan.gc.ca/ censusrecensement/ 2016/ dp-pd/ prof/ details/ page.cfm?Lang=E\&G e01=CSD \&Code1=5917034\&G eo2=CD \& Code2 $=5917 \& D$ ata $=$ Count\&SearchText=Capital $\&$ SearchType $=$ Begins\&SearchPR=01\&B1=All\&G eoLevel=PR\& GeoCode $=5917 \&$ TABID $=1$

Statistics Canada. (2017b). Table 1: The 10 highest population densities among municipalities (census subdivisions) with 5,000 residents or more, Canada, 2016 [Table]. Retrieved from https:/ / www150.statcan.gc.ca/ n1/ dailyquotidien/ 170208/ t001a-eng.htm

Twiss, J., D ickinson, J., D uma, S., Kleinman, T., Paulsen, H., \& Rilveria, L. (2003). Community gardens: Lessons learned from California Healthy Cities and Communities. A merican Journal of $\mathrm{P}$ ublic $\mathrm{H}$ ealth, 93(9), 1435-1438. https:// doi.org/ 10.2105/ AJPH.93.9.1435

Viljoen, A., Bohn, K., \& Howe, J. (2005). C ontinuous productive urban landscapes. Burlington, Massachusetts: Architectural Press. 